\title{
A Simple, Variable Form Volume Estimation System
}

\author{
by
}

\author{
David D. Reed and John C. Byrne ${ }^{1}$
}

\begin{abstract}
A volume estimation system giving the stem profile (upper stem diameter outside bark), total tree volume, and merchantable volume to a height or diameter limit is developed based on a simple, variable form stem taper curve. The stem taper curve is defined by coefficient values indicating conic and parabolic tree forms. For a given height, small diameter trees are assigned parabolic forms and large diameter trees are assigned conic forms. A tree's position in the tree form continuum is defined by its total height to diameter at breast height ratio. Performance of the volume estimation system is evaluated using stem analysis information on red pine, jack pine, and white spruce from the upper Great Lakes Region.
\end{abstract}

Key words: Pinus resinosa Ait., Pinus banksiana Lamb., Picea glauca (Moench) Voss, taper curve, merchantable volume, volume ratio, total tree volume.

\section{Résumé}

Un système d'évaluation du volume tenant compte du profil de la tige (diamètre avec écorce de la section supérieure de la tige), du volume de l'arbre entier, et du volume marchand à une certaine hauteur ou diamètre limite a été développé d'après une courbe simple du défilement de la tige suivant sa forme variable. La courbe du défilement de la tige est définie par les valeurs du coefficient indiquant les formes coniques ou paraboliques de l'arbre. Pour une hauteur donnée, les arbres à petits diamètres se voient assigner des formes paraboliques et les arbres à grands diamètres, des formes coniques. Une position d'arbre dans le continuum de la forme des arbres est définie comme étant un rapport hauteur totale/diamètre à hauteur de poitrine. La performance de ce système d'évaluation du volume est comparée avec l'information obtenue par l'analyse des tiges de pin rouge, pin gris et épinette blanche de la région supérieure des Grands Lacs.

\section{Introduction}

Ormerod (1971) gave a simple model in which a tree's profile is described as follows:

$$
d=D\left[\frac{H-h}{H-1.37}\right]^{b,}
$$

where:

$\mathrm{d}=$ upper stem diameter in centimeters

$\mathrm{D}=$ diameter at breast height $(1.37 \mathrm{~m}$ from the ground $)$ in centimeters

$\mathrm{H}=$ total tree height in meters

$h=$ partial tree height $(0<h<H)$ in meters

$b_{1}=a$ coefficient to be estimated

As discussed by Forslund (1982) when $b_{1}$ takes on a value of one, the resulting tree profile is conic and when $b_{1}$ is one-half the resulting tree profile is parabolic. Forslund recommended a shape in between a cone and a parabola, a "paracone", where $b_{1}$ is equal to three-fourths.

The authors are, respectively, Assistant Professor and Graduate Research Assistant, School of Forestry and Wood Products. Michigan Technological University, Houghton, MI 49931 USA
Whenever a taper curve is estimated, the coefficients define an "average" tree form for the data. Likewise, specifying a value of $b_{1}$ in Ormerod's curve defines a common "average" tree form. Trees of different species may obviously have different forms and the authors have observed that trees of a single species in a single stand also tend to show differences in form. Dominant trees tend to be taller and larger in diameter and take on a more conical form than the more cylindrical intermediate and suppressed trees which tend to be more parabolic. The object of this study was to develop a simple, variable form taper equation accounting for these differences in form. Compatible total and merchantable volume equations were developed based on the simple, variable form taper equation (Reed and Green 1984).

\section{Data}

Stem analysis from the following northern conifer species were utilized in this study: red pine (Pinus resinosa Ait.), jack pine (Pinus banksiana Lamb.), and white spruce (Picea glauca (Moench) Voss). The trees were felled and sectioned at $1.22 \mathrm{~m}$ (four foot) intervals with the diameters inside and outside bark (in centimeters) and height from ground (in 
meters) recorded. Some of the white spruce were sectioned at approximately $3.66 \mathrm{~m}$ (12 foot) intervals. The tree's diameter at breast height and total height were also recorded. These data are summarized in Table 1. Volumes were calculated from the ground to each height/diameter observation and for the total tree using Smalian's formula (Avery and Burkhart 1983).

\begin{tabular}{|c|c|c|c|}
\hline \multirow[b]{2}{*}{ Variable } & \multicolumn{3}{|c|}{ Species } \\
\hline & Red pine & Jack pine & $\begin{array}{l}\text { White } \\
\text { spruce }\end{array}$ \\
\hline Number of trees & 77 & 27 & 14 \\
\hline $\begin{array}{l}\text { Number of height/diameter } \\
\text { observations }\end{array}$ & 1055 & 390 & 122 \\
\hline \multicolumn{4}{|l|}{ Diameter at breast height $(\mathrm{cm})$} \\
\hline Average & 23.3 & 22.0 & 21.0 \\
\hline Standard deviation & 3.61 & 4.16 & 3.81 \\
\hline Range & $16.0,31.0$ & $18.0,28.4$ & $15.2,31.0$ \\
\hline \multicolumn{4}{|l|}{ Total tree height (m) } \\
\hline Average & 17.7 & 18.8 & 13.8 \\
\hline Standard deviation & 2.44 & 2.56 & 2.62 \\
\hline Range & $12.8,21.5$ & $13.7,22.0$ & $10.1,20.1$ \\
\hline \multicolumn{4}{|l|}{ Total tree volume $\left(\mathrm{m}^{3}\right)$} \\
\hline Average & 0.40 & 0.36 & 0.24 \\
\hline Standard deviation & 0.16 & 0.13 & 0.11 \\
\hline Range & $0.14,0.76$ & $0.21,0.68$ & $0.10,0.52$ \\
\hline \multicolumn{4}{|l|}{$b_{1}$ Coefficient } \\
\hline Average & 0.612 & 0.531 & 0.700 \\
\hline Standard deviation & 0.068 & 0.104 & 0.035 \\
\hline Range & $0.348,0.755$ & $0.399,0.776$ & $0.617,0.750$ \\
\hline
\end{tabular}

The topmost section was assumed to be conic in the calculation of volumes. In this case, the volume of the lowermost section was calculated assuming a cylinder from the ground to the lowest height/diameter observation. In the white spruce, the lowest height/diameter ratio was occasionally as high as $3.66 \mathrm{~m}$ (12 feet) or more from the ground. In the red pine, jack pine, and most of the white spruce, the lowest measurement was usually .15 to $.20 \mathrm{~m}$ (approximately 0.5 feet) from the ground at the stump.

\section{Methods}

The three species were first analyzed independently to examine tree form. The red pine and jack pine tended to be tall with smaller diameters and best represented by a parabolic to "paraconic" tree form. The white spruce tended to most closely resemble the "paracone" described by Forslund (1982). The value of $b_{1}$ from Ormerod's taper curve was taken to be the indicator of shape in this analysis $\left(b_{1}=1\right.$ indicates a cone, $b_{1}=1 / 2$ indicates a parabola).

Following this empirical examination of the three species and numerous individual trees, it became apparent that those trees in the data with low total height:diameter at breast height $(H: D)$ ratios (30:1 when expressed in common units) were more conical with $b_{1}$ values close to one and those trees with high $H: D$ ratios (90:1 when expressed in common units) were parabolic with $b_{1}$ values close to one-half. Most trees fell somewhere in between these two extremes but a few individuals did possess $H: D$ ratios less than $30: 1$ (Table 1).

These $H: D$ ratios were used as the basis for a variable form taper curve. Ormerod's equation was taken as the basic taper curve and $b_{1}$ was derived separately for each tree depending on the tree's total height and diameter at breast height:

$$
b_{1}=1-\left[\frac{(H / D)-30}{120}\right]
$$

where $\mathrm{H}$ and $\mathrm{D}$ are expressed in common units. This results in $b_{1}=1$ when $H / D=30$ and $b_{1}=1 / 2$ when $H / D=90$. Trees with $H: D$ ratios greater than $90: 1$ tend to be more cylindrical than a parabola. This expression uses a linear interpolation to estimate $b_{1}$ when $30<(H / D)<90$.

The $b_{1}$ value for each tree is estimated with equation [2] and used in Ormerod's taper curve to estimate upper stem diameter. The taper curve can be integrated to produce a total tree volume (TV) equation (Kozak et al 1969), where TV is defined as the total outside bark tree volume in $\mathrm{m}^{3}$ :

$$
T V=\frac{0.00007854}{\left(2 b_{1}+1\right)} D^{2}\left[\frac{H^{2 b_{1}+1}}{(H-1.37)^{2 b_{1}}}\right]
$$

Volume ratio equations (Burkhart 1977; Cao and Burkhart 1980 ) can be developed from the taper curve (Reed and Green 1984). In these equations, merchantable volume (MV) is defined as volume outside bark from the ground to some height or diameter limit in $\mathrm{m}^{3}$ and is expressed in terms of total volume, TV, and a ratio, $R$ :

$$
M V=T V * R
$$

For the taper curve discussed above, a ratio equation based on a limiting height is given by:

$$
R_{h}=1-\left[\frac{H-h}{H}\right]^{2 b_{1}+1}
$$

and a ratio equation based on upper stem diameter is given by:

$$
R_{d}=1-\left[\frac{H-1.37}{H}\right]^{2 b_{1}+1}\left[\frac{d}{D}\right] \frac{2 b_{1}+1}{b_{1}}
$$

These four components (the stem taper equation, the total volume equation, and the volume ratio equations based on a limiting height and upper stem diameter) make up the variable form volume estimation system. This volume estimation system was then evaluated using the data from the three species discussed previously.

\section{Results and Discussion}

The total volume equation (equation [3]) was used to estimate the total volume of each tree in the data while the taper curve (equations [1] and [2]) and volume ratio equations (equations [5] and [6]) were used to estimate outside bark diameter and merchantable volume for each height/diameter observation in the data. The resulting average residual (the residual being the respective observed value minus the predicted), the standard deviation of residuals, and the range in residuals are given by species in Table 2 .

The stem taper curve performed best on the white spruce and the red pine data. It tended to overpredict (indicated by a negative average residual) on the jack pine. The jack pine tended to be tall and have small diameters with $H: D$ ratios surpassing 90:1 in several instances. The equation may be predicting too cylindrical (i.e. a $b_{1}$ value less than 0.5 ) a tree form for this species.

The total tree volume equation also performed well on red pine and white spruce. The jack pine volumes were slightly overestimated, probably owing to the reasons discussed above. The merchantable volume prediction based on the height limit performed well for all three species. The merchantable volume prediction based on upper stem diameter performed well with an average residual near zero for all three 
Table 2. Test results of the derived volume estimation system by species. less reliable (indicated by a higher standard deviation and greater range of residuals) than that based on height. This agrees with observations made by Reed and Green (1984) and Van Deusen et al (1982).

As a further evaluation of the predictive ability of the volume estimation system, predictions were evaluated for different sections of the tree bole (Table 3). The taper curve tended to slightly underpredict diameters in the lower stem and overpredict diameters in the upper stem for red pine and white spruce. This would indicate that the individual trees are not as parabolic as the curve indicates. A slight overprediction of diameter over much of the stem was indicated in the jack pine data with the overprediction becoming more severe near the top of the tree.

The prediction of merchantable volume based on a height limit performed well over the entire stem for red pine and white spruce and did well in the upper bole of jack pine. The prediction of merchantable volume based on upper stem diameter performed well for jack pine; for the other two species it tended to be more erratic at every location in the stem than the merchantable volume predictions based on height.

Attempts at improving the performance of the volume estimation system included varying the value of the $H: D$ ratios defining the conic and parabolic tree forms. The results indicated that little was to be gained by varying these ratios over a large range $(+30$ percent was attempted with little improvement). This would seem to indicate that the simple shapes assumed by the volume estimation system (cone-paracone-parabola) are approximations whose performance will vary by species. Improved knowledge of the effect of physical and physiological characteristics of a species on form will allow increased interpretive ability and improved system performance.

\section{Conclusions}

A system estimating upper stem diameter, total tree volume, and merchantable volume to either a diameter or height limit has been developed based on a simple, variable form stem taper equation. The stem taper equation varies the form of the tree based on the ratio of total tree height to diameter at breast height. The stem taper equation is based on the observation that, for a given height, small diameter trees tend to be para-

\begin{tabular}{|c|c|c|c|c|c|c|c|c|c|c|}
\hline \multirow{3}{*}{$\begin{array}{l}\text { Location in the } \\
\text { tree bole }\end{array}$} & \multirow{3}{*}{$\begin{array}{l}\text { Number of } \\
\text { observations }\end{array}$} & \multicolumn{3}{|c|}{ Diameter outside bark $(\mathrm{cm})$} & \multicolumn{6}{|c|}{ Merchantable volume $\left(\mathrm{m}^{3}\right)$} \\
\hline & & \multirow[b]{2}{*}{$\mathbf{R}$} & \multirow[b]{2}{*}{$S_{R}$} & \multirow[b]{2}{*}{ Range } & \multicolumn{3}{|c|}{ Height limit } & \multicolumn{3}{|c|}{ Diameter limit } \\
\hline & & & & & $\mathbf{R}$ & $s_{R}$ & Range & $\mathbf{R}$ & $s_{R}$ & Range \\
\hline \multicolumn{11}{|l|}{0.0 to $4.0 \mathrm{~m}$} \\
\hline Red pine & 231 & 0.08 & 0.58 & $-1.52,2.03$ & 0.00 & 0.01 & $-0.02,0.02$ & 0.00 & 0.02 & $-0.06,0.09$ \\
\hline Jack pine & 81 & -0.10 & 0.61 & $-1.52,1.27$ & 0.06 & 0.01 & $-0.02,0.03$ & 0.00 & 0.03 & $-0.06,0.10$ \\
\hline White spruce & 39 & 0.20 & 0.53 & $-0.51,2.03$ & -0.00 & 0.00 & $-0.01,0.01$ & 0.00 & 0.01 & $-0.01,0.04$ \\
\hline \multicolumn{11}{|l|}{4.0 to $7.9 \mathrm{~m}$} \\
\hline Red pine & 231 & 0.41 & 0.76 & $-3.05,2.54$ & 0.00 & 0.01 & $-0.02,0.02$ & 0.01 & 0.02 & $-0.05,0.13$ \\
\hline Jack pine & 81 & -0.30 & 0.91 & $-1.78,2.79$ & 0.01 & 0.01 & $-0.02,0.04$ & -0.00 & 0.02 & $-0.04,0.07$ \\
\hline White spruce & 37 & 0.74 & 0.79 & $-2.29,2.03$ & 0.00 & 0.01 & $-0.01,0.03$ & 0.01 & 0.01 & $-0.04,0.03$ \\
\hline \multicolumn{11}{|l|}{7.9 to $11.9 \mathrm{~m}$} \\
\hline Red pine & 231 & 0.38 & 0.84 & $-2.03,2.29$ & 0.00 & 0.01 & $-0.01,0.02$ & 0.01 & 0.02 & $-0.03,0.09$ \\
\hline Jack pine & 81 & -0.66 & 1.12 & $-2.29,4.83$ & 0.01 & 0.01 & $-0.01,0.04$ & 0.00 & 0.01 & $-0.03,0.04$ \\
\hline White spruce & 33 & -0.30 & 0.86 & $-1.78,1.52$ & 0.00 & 0.00 & $-0.00,0.01$ & 0.00 & 0.00 & $-0.00,0.01$ \\
\hline \multicolumn{11}{|l|}{11.9 to $15.9 \mathrm{~m}$} \\
\hline Red pine & 215 & -0.53 & 1.12 & $-3.05,3.05$ & 0.00 & 0.00 & $-0.01,0.02$ & 0.01 & 0.01 & $-0.01,0.06$ \\
\hline Jack pine & 73 & -1.55 & 1.02 & $-3.81,1.52$ & 0.01 & 0.01 & $-0.00,0.03$ & -0.01 & 0.01 & $-0.01,0.03$ \\
\hline White spruce & 13 & -0.94 & 0.74 & $-2.03,0.25$ & 0.00 & 0.00 & $-0.00,0.00$ & -0.00 & 0.00 & $-0.00,0.00$ \\
\hline \multicolumn{11}{|l|}{15.9 to $19.8 \mathrm{~m}$} \\
\hline Red pine & 142 & -1.65 & 1.02 & $-6.10,1.02$ & 0.00 & 0.00 & $-0.00,0.01$ & 0.00 & 0.00 & $-0.00,0.01$ \\
\hline Jack pine & 70 & -2.92 & -1.55 & $-4.83,-0.51$ & 0.01 & 0.00 & $0.00,0.02$ & -0.00 & 0.00 & $-0.00,0.00$ \\
\hline White spruce & 0 & - & - &,-- & - & - &,-- & - & - &,-- \\
\hline \multicolumn{11}{|l|}{19.8 to $23.8 \mathrm{~m}$} \\
\hline Red pine & 5 & -0.76 & 0.56 & $-1.52, \quad 0.00$ & 0.00 & 0,00 & $-0.00,0.00$ & -0.00 & -0.00 & $-0.00,0.00$ \\
\hline Jack pine & 3 & -2.97 & 0.15 & $-3.05,2.79$ & 0.00 & 0.00 & $-0.00,0.00$ & -0.00 & 0.00 & $-0.00,0.00$ \\
\hline White spruce & 0 & - & - &,-- & - & - &,-- & - & - &,-- \\
\hline
\end{tabular}

$\mathrm{R} \quad$ = Average residual (Observed value minus predicted value)

$\mathrm{S}_{\mathrm{R}}=$ Standard deviation of residuals

Range $=$ Range of residuals 
bolic in form and large diameter trees tend to be conic.

These observations were made on three species of northern conifers: red pine, jack pine, and white spruce. While the performance of the system varied by species, the volume estimation system presented here is fast and easy to apply, produces a large amount of information concerning a tree, and seems to perform well on a variety of species, especially those falling into the interior of the conic-parabolic tree form continuum.

\section{Acknowledgments}

The authors express their appreciation to Champion International Corporation and the Ford Forestry Center, Michigan Technological University, L'Anse, MI for making stem analysis data available. This study was supported in part by McIntire-Stennis Act funds.

\section{References}

Avery, T.E. and H.E. Burkhart. 1983. Forest Measurement. Third Edition. McGraw-Hill, New York. 331 p.
Burkhart, H.E. 1977. Cubic-foot volume of loblolly pine to any merchantable top limit. South J. Appl. For. 1:7-9.

Cao, Q.V. and H.E. Burkhart. 1980. Cubic-foot volume of loblolly pine to any height limit. South J. Appl. For. 4:166-168.

Forslund, R.R. 1982. A geometrical tree volume model based on the location of the centre of gravity of the bole. Can. J. For. Res. 12:215-221.

Kozak, A., D.D. Munro and J.H.G. Smith. 1969. Taper functions and their application in forest inventory. For. Chron. 45:278-283.

Ormerod, D.W. 1973. A simple bole model. For. Chron. 49:136-138

Reed, D.D. and E.J. Green. 1984. Compatible stem taper and volume ratio equations. Forest Sci. 30:977-990.

Van Deusen, P.C., T.G. Matney and A.D. Sullivan. 1982. A compatible system for predicting the volume and diameter of sweetgum trees to any height. South J. Appl. For. 6:159-163.

\section{Woodlot Service (1978) Ltd.}

"All Matters Pertalning to Forestry"

\author{
GORDON B. YOUNG, B.Sc.F., M.F. \\ Registered Professional Forester
}

320 Maple Street

Bus.: $506-472-3396$

Fredericton, N.B.

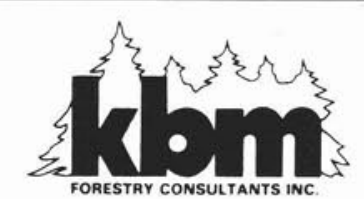

360 mooney street thunder bay, ontario P7B 5R4

\section{REFORESTATION EQUIPMENT \\ - Sales Service Parts Repair}

REGENERATION \& SITE PREPARATION

- Contract Assessment Consulting

807-344-0811 telex 073-4603 